\title{
Comparative study of ranavirus isolates from cod (Gadus morhua) and turbot (Psetta maxima) with reference to other ranaviruses
}

\author{
Ellen Ariel · Riikka Holopainen • Niels Jørgen Olesen • \\ Hannele Tapiovaara
}

Received: 24 February 2010/Accepted: 25 May 2010/Published online: 15 June 2010

(C) Springer-Verlag 2010

\begin{abstract}
Two iridovirus isolates recovered from cod (Gadus morhua) and turbot (Psetta maxima) in Denmark were examined in parallel with a panel of other ranaviruses including frog virus 3 (FV3), the reference strain for the genus Ranavirus. The isolates were assessed according to their reactivity in immunofluoresent antibody tests (IFAT) using both homologous and heterologous antisera and their amplification in PCR using primers targeting five genomic regions. The corresponding PCR fragments were sequenced, and the sequences obtained were used in phylogenetic analysis. In addition, the pathogenicity to rainbow trout under experimental challenge conditions was investigated. The viruses were serologically and genetically closely related to highly pathogenic ranaviruses such as European catfish iridovirus (ECV), European sheatfish iridovirus (ESV) and epizootic haematopoietic necrosis virus $(\mathrm{EHNV})$. The challenge trials indicate that rainbow trout fry cultured at $15^{\circ} \mathrm{C}$ are not target species for the virus isolates in the present panel. We suggest that the two isolates belong in the genus Ranavirus and propose the name Ranavirus maxima (Rmax) for the turbot isolate.
\end{abstract}

E. Ariel · N. J. Olesen

National Veterinary Institute, Technical University of Denmark, Århus, Denmark

R. Holopainen $\cdot$ H. Tapiovaara

Department of Veterinary Virology, Finnish Food Safety

Authority Evira, Helsinki, Finland

E. Ariel $(\bowtie)$

School of Veterinary and Biomedical Sciences, James Cook University, Townsville, QLD 4811, Australia e-mail: Ellen.Ariel@jcu.edu.au

\section{Introduction}

Ranavirus is a genus in the family Iridoviridae [1]. It possesses a large dsDNA genome, which is replicated in two stages, the main replication occurring in the nucleus, and the second phase of replication in the cytoplasm of the host cell [2]. Virions exit the host cell either by budding, whereby they obtain a host-derived envelope, or by cell lysis [1]. Ranaviruses cause disease in both amphibians [3-6] and reptiles [7-12] and have progressively become prominent pathogens of fish on a global scale. Some isolates are highly pathogenic and cause systemic infection in both cultured and free-living fish. Epizootic haematopoietic necrosis virus (EHNV) was isolated from redfin perch (Perca fluviatilis) in Australia during an epizootic outbreak $[13,14]$ and later from rainbow trout (Oncorhyncus mykiss) [15]. In 1989, Ahne et al. [16] reported an incidence of high mortality in sheatfish (Silurus glanis) associated with a ranavirus, and in 1992 and 1993, a ranavirus was found to cause high mortality in catfish (Ameiurus melas) in France and Italy [17, 18]. Repeated epizootics caused by ranaviruses in northern Italy have all but put an end to the Ameiurus melas industry in that area. Other ranavirus isolates such as pike perch iridovirus (PPIV) and short-finned eel ranavirus (SERV) appear to be have been isolated by chance from symptomless fish from both freshwater and marine environments $[19,20]$.

Frog virus 3 (FV3) is the type species of the genus Ranavirus, and was isolated from a frog with a tumour [21]. Bohle iridovirus (BIV) was isolated from moribund tadpoles [22] and caused mortality in other species of frogs under experimental conditions, especially in the metamorphosis stage [23]. It was also found to be highly pathogenic to certain fish, showing an ability to infect hosts from different classes [24, 25]. Rana esculenta virus 282/I02 (REV 
282/I02) was isolated from moribund tadpoles [26]. Many reports of ranaviruses in amphibians have been published and linked to the worldwide decline in frogs [27-29].

The two Danish isolates that are the focus of this study were isolated from apparently healthy fish. Cod iridovirus (CodV) was identified during an investigation of the cause of ulcus syndrome in free-living populations of cod (Gadus morhus) in Danish waters, and the infected fish were caught in Lillebælt, the narrow strait between Jutland and Fynen [30]. The ranavirus isolated from cod was one of several suspected etiological agents, none of which was ever confirmed as the cause of the ulcers [30]. An iridovirus was visualized by EM in several organs in turbot (Psetta maxima) fry with general disease symptoms and $70 \%$ mortality [31]. It was only in 1999 that a virus was isolated during a general health certification of apparently healthy turbot fry from the same aquaculture facility. There are recent reports of iridoviruses in farmed turbot from China and Korea [32, 33]. They both appear to belong to the proposed genus Megalocytivirus within the family Iridoviridae.

Several comparative studies have been carried out on ranaviruses [34-37], with the findings that BIV, EHNV, $\mathrm{ECV}$ and ESV are distinct isolates that are similar to each other and to FV3 in terms of morphology, size, number and weight of structural proteins, and appear to share antigens that cause cross-reactivity in serology.

Infection with ranavirus is listed by the Office International des Epizooties (OIE) as a notifiable disease for amphibians; for fish, EHNV is the only notifiable ranavirus. This paper reports on a study comparing two Danish ranavirus-like isolates to notifiable and other ranaviruses with respect to their reactivity in IFAT with polyclonal antisera, sequencing of the major capsid protein (MCP), DNA polymerase (DNApol), RNase III, ribonucleoside diphosphate reductase alpha (RNR- $\alpha)$ and beta (RNR- $\beta$ ) subunit genes, and the pathogenicity of the isolates in experimental challenge of rainbow trout (Onchorhyncus mykiss) fry at $15^{\circ} \mathrm{C}$.

\section{Materials and methods}

Viruses and cell culture

Ranavirus (DK-9995205) was isolated from turbot fry with no clinical signs in the spring of 1999 as part of health certification for export. The fish were investigated for the presence of viruses by cell culture and nodavirus by standard histological and immunohistochemical examination. The ranavirus was isolated from tissue homogenate of fry diluted 1:10 in cell culture medium. The suspension was centrifuged at $4000 \times g$ and the resultant supernatant was inoculated onto bluegill fry (BF-2) cells [38] and striped snakehead (SSN-1) cells [39] at two dilutions $\left(10^{-1}\right.$ and $10^{-2}$ ). In addition to CodV and Rmax, nine other isolates were included in the investigation: BIV, EHNV, ECV (French and Italian isolates), ESV, FV3, PPIV, REV282/ I02 and SERV (Table 1). The isolates were propagated and titrated in BF-2 cells prior to use in the different laboratory investigations and the experimental challenge trials. The cells were grown at $20^{\circ} \mathrm{C}$ in Eagle's MEM supplemented with $10 \%$ foetal bovine serum, $1 \%$ glutamine, $100 \mathrm{IU} / \mathrm{ml}$ penicillin and $40 \mathrm{~g} / \mathrm{ml}$ streptomycin. After inoculation with virus, the flasks were transferred to a $15^{\circ} \mathrm{C}$ incubator. The cells were grown in either $25-$ or $175-\mathrm{cm}^{2}$ tissue culture flasks (Nunc A/S; Roskilde, Denmark). At full cytopathic effect (CPE), the suspensions underwent three cycles of freeze-thawing, after which the cell debris were separated from the viral suspension by centrifugation at $4,000 \times g$. The virus was stored at $-80^{\circ} \mathrm{C}$. For titration of infectious virus, six replicates of tenfold dilutions of virus were inoculated into subconfluent BF-2 cells in 96-well plates (Nunc A/S; Roskilde, Denmark), and the titre was calculated as $50 \%$ tissue culture infective dose $\left(\mathrm{TCID}_{50}\right)$ according to Reed and Muench [40] prior to use in laboratory testing and in experimental challenge.

Virus purification was carried out according to Hedrick et al. [34], with slight modifications: Virus was pelleted from the supernatant prepared as above by a 60-min ultracentrifugation in a Beckman SW 28 rotor at $20,000 \mathrm{rpm}$ at $+4^{\circ} \mathrm{C}$. The pellet was resuspended in $1 \mathrm{ml}$ of TN buffer ( $50 \mathrm{mM}$ Tris- $\mathrm{HCl}, \mathrm{pH} 7.5,150 \mathrm{mM} \mathrm{NaCl})$, layered on top of a $20-60 \%$ w/v continuous sucrose gradient and ultracentrifuged in a Beckman L8-60 M SW 41 rotor at $34,000 \mathrm{rpm}$ for $60 \mathrm{~min}$ at $+4^{\circ} \mathrm{C}$. The resulting opalescent viral bands were collected by aspiration, diluted in TN buffer and pelleted in a Beckman SW 28 rotor at $20,000 \mathrm{rpm}$ for $60 \mathrm{~min}$ at $+4^{\circ} \mathrm{C}$. The final virus pellet was resuspended in $200 \mu \mathrm{l}$ of $\mathrm{TN}$ buffer, aliquoted and frozen at $-80^{\circ} \mathrm{C}$.

Polyclonal antisera

Two New Zealand white rabbits, F61 and F62, were immunized by intraperitoneal and subcutaneous injection according to the protocols described by Olesen et al. [41].

Staining of cells for immunofluorescence

A 1:1,000 dilution of each of the isolates in the panel was added to cover-glass cultures of epithelioma papulosum cyprini (EPC) cells (Fijan et al. 1983). The cultures were incubated for $72 \mathrm{~h}$ at $15^{\circ} \mathrm{C}$. They were then rinsed and fixed in $80 \%$ acetone prior to immunofluorescence staining as described by Jørgensen et al. [42]. Primary antibodies (rabbit sera) produced against specific isolates were tested 
Table 1 Ranavirus isolates used in this investigation, with reference to original host, first publication and supplier

\begin{tabular}{|c|c|c|c|c|c|c|c|}
\hline Virus & Acronym & Host & Reference & $\begin{array}{l}\text { Isolate } \\
\text { obtained } \\
\text { from }\end{array}$ & $\begin{array}{l}\text { Infection } \\
\text { trials }\end{array}$ & IFAT & $\begin{array}{l}\text { Molecular } \\
\text { studies }\end{array}$ \\
\hline Bohle iridovirus & BIV & $\begin{array}{l}\text { Burrowing frog } \\
\text { (Limnodynastes } \\
\text { ornatus) }\end{array}$ & Speare and Smith [22] & L.Owens $^{\mathrm{a}}$ & $\mathrm{X}$ & $\mathrm{X}$ & ND \\
\hline Bohle iridovirus & BIV & $\begin{array}{l}\text { Burrowing frog } \\
\text { (Limnodynastes } \\
\text { ornatus) }\end{array}$ & Speare and Smith [22] & A. Hyatt ${ }^{\mathrm{b}}$ & ND & $\mathrm{X}$ & $\mathrm{X}$ \\
\hline Cod ranavirus & CodV & Cod (Gadus morhua) & Jensen et al. [30] & J.L. Larsen ${ }^{c}$ & $X$ & $\mathrm{X}$ & $\mathrm{X}$ \\
\hline $\begin{array}{l}\text { Epizootic } \\
\text { haematopoietic } \\
\text { necrosis virus }\end{array}$ & EHNV & $\begin{array}{l}\text { Red-fin perch (Perca } \\
\text { fluviatilis) }\end{array}$ & Langdon et al. [13] & R. Whittington ${ }^{\mathrm{d}}$ & $X$ & $X$ & $X$ \\
\hline $\begin{array}{l}\text { European catfish virus } \\
\text { (France) }\end{array}$ & $\mathrm{ECV}(\mathrm{Fr})$ & $\begin{array}{l}\text { European catfish } \\
\quad \text { (Ameiurus melas) }\end{array}$ & Pozet et al. [17] & G. Bovo ${ }^{\mathrm{e}}$ & $\mathrm{X}$ & $\mathrm{X}$ & ND \\
\hline $\begin{array}{l}\text { European catfish virus } \\
\text { (Italy) }\end{array}$ & ECV (It) & $\begin{array}{l}\text { European catfish } \\
\quad \text { (Ameiurus melas) }\end{array}$ & Bovo et al. [18] & G. Bovo ${ }^{e}$ & $\mathrm{X}$ & $\mathrm{X}$ & $X$ \\
\hline European sheatfish virus & ESV & $\begin{array}{l}\text { European sheatfish } \\
\text { (Silurus glanis) }\end{array}$ & Ahne et al. [16] & W. Ahne ${ }^{f}$ & $\mathrm{X}$ & $\mathrm{X}$ & $\mathrm{X}$ \\
\hline Frog virus 3 & FV3 & $\begin{array}{l}\text { Leopard frog (Rana } \\
\text { pipiens) }\end{array}$ & Granoff et al. [21] & W. Ahne ${ }^{f}$ & $X$ & $\mathrm{X}$ & $\mathrm{X}$ \\
\hline Pike-perch iridovirus & PPIV & $\begin{array}{l}\text { Pike-perch (Stizostedion } \\
\text { lucioperca) }\end{array}$ & Tapiovaara et al. [19] & & $X$ & $X$ & $X$ \\
\hline $\begin{array}{l}\text { Rana esculenta virus } \\
282 / \mathrm{I} 02\end{array}$ & REV 282/I02 & $\begin{array}{l}\text { Edible frog (Pelophylax } \\
\text { esculentus) }\end{array}$ & $\begin{array}{l}\text { G. Bovo pers. comm.; } \\
\text { Holopainen et al. [26] }\end{array}$ & G. Bovo & ND & $\mathrm{X}$ & $X$ \\
\hline Ranavirus maxima & $\begin{array}{r}\text { Rmax DK } \\
9995205\end{array}$ & Turbot (Psetta maxima) & & & $X$ & $\mathrm{X}$ & $X$ \\
\hline $\begin{array}{l}\text { Short-finned eel } \\
\text { ranavirus }\end{array}$ & SERV & $\begin{array}{l}\text { Short-finned eel } \\
\quad \text { (Anguilla australis) }\end{array}$ & Bang Jensen et al. [20] & G. Bovo ${ }^{e}$ & ND & $\mathrm{X}$ & $\mathrm{X}$ \\
\hline
\end{tabular}

$X$ included, $N D$ not done

a James Cook University

b Australian Animal Health Laboratory, Australia

c University of Copenhagen

${ }^{\mathrm{d}}$ University of Sydney, Australia

e Instituto Zooprofilattico delle Venezie, Italy

${ }^{\mathrm{f}}$ University of Munich, Germany

for reactivity to homologous and heterologous isolates at 1:800 dilution and incubated for $30 \mathrm{~min}$ at $37^{\circ} \mathrm{C}$. Additionally, a monoclonal antibody against red sea bream iridovirus (RSIV) was tested with the panel at a 1:10 dilution, as were antisera against infectious pancreatic necrosis virus (IPNV) serotypes $\mathrm{Sp}$ and $\mathrm{Ab}$ [43], using the rabbit sera F48 + F51 batch 18.11.1998, and lake trout rhabdovirus (LTR) [44], with rabbit serum K 2705-02.04.90 [45] at a dilution of 1:1,000. The antisera were kindly made available by P. de Kinkelin (anti-EHNV, -ECV (Fr), -ESIV), G. Bovo (anti-ECV(It)) and K. Nakajima (anti-RSIV), or produced at the National Veterinary Institute, Denmark, and National Veterinary and Food Research Institute, Finland (anti-BIV, -CodV, -PPIV, -Rmax, -IPN, -LTR). Rhodamine- or fluorescein-conjugated swine antibodies to rabbit immunoglobulin (R015 and F0205, respectively,
Dako, Copenhagen, Denmark) at a dilution of 1:100 and 1:40, respectively, were applied as secondary antisera for 30 min at $37^{\circ} \mathrm{C}$.

DNA extraction, PCR amplification, DNA sequencing and sequence analysis

CodV DNA was extracted from concentrated virus preparations by ultracentrifugation. The DNA of Rmax was purified directly from growth medium collected from virusinfected cell culture after freezing and thawing three times. Twenty microlitre of purified virus suspension or $200 \mu \mathrm{l}$ growth medium was used for DNA extraction. The preparations were lysed with $200 \mu \mathrm{l}$ of DNA extraction buffer containing $10 \mathrm{mM}$ Tris, $\mathrm{pH} 7.5,100 \mathrm{mM} \mathrm{NaCl}, 5 \mathrm{mM}$ EDTA and 2\% SDS. Proteinase K (final concentration 
$200 \mu \mathrm{g} / \mathrm{ml}$ ) was added, and the lysates were incubated overnight at $37^{\circ} \mathrm{C}$. The lysates were extracted twice with phenol-chloroform, and DNA was precipitated overnight at $-20^{\circ} \mathrm{C}$ with ethanol containing $0.3 \mathrm{M}$ sodium acetate. The dried DNA was dissolved in 10-20 $\mu \mathrm{l}$ of sterile water.

The nucleotide sequence of the complete MCP gene region and partial sequences of DNApol, RNase III, RNR- $\alpha$ and RNR- $\beta$ subunit genes were analysed in this study. Several PCR primer pairs (Table 2) were used in the amplification of the different genomic regions. The entire open reading frame (ORF) of the MCP gene was amplified in three overlapping fragments. One primer pair for each gene was used to obtain partial gene sequences of DNApol, RNase III, RNR- $\alpha$ and RNR- $\beta$ genes.

The PCR conditions for primer pairs MCP-AF \& MCP-AR and MCP-BF \& MCP-BR were as follows: 35 cycles of $95^{\circ} \mathrm{C}$ for $1 \mathrm{~min}, 55^{\circ} \mathrm{C}$ for $1 \mathrm{~min}$, and $72^{\circ} \mathrm{C}$ for 1 min. For primer pairs RNase III-F \& RNase III-R, RNR-AF \& RNR-AR and RNR-BF \& RNR-BR, the cycling conditions were 25 cycles of $95^{\circ} \mathrm{C}$ for $1 \mathrm{~min}$, $50^{\circ} \mathrm{C}$ for $2 \mathrm{~min}$, and $72^{\circ} \mathrm{C}$ for $2 \mathrm{~min}$. The PCR reaction mixture contained $0.5 \mu \mathrm{M}$ of each primer, $160 \mu \mathrm{M}$ of each nucleotide (dATP, dTTP, dGTP, dCTP), 10× PCR buffer (150 mM Tris-HCl, $500 \mathrm{mM} \mathrm{KCl,} \mathrm{pH} \mathrm{8.3),} 1 \mathrm{mM}$ $\mathrm{MgCl}_{2}$ and 2 units of Taq polymerase (AmpliTaq Gold, Applied Biosystems). The sequences of primer pairs MCP-5 \& MCP-6R and DNApol-F \& DNApol-R, as wells as with the suitable PCR conditions, were published by Hyatt et al. [37] and Holopainen et al. [26], respectively. At least two independent amplification events were performed for each gene region to eliminate errors introduced by the polymerase.

Amplified PCR fragments were purified using MinElute PCR purification colums (Qiagen, Valencia, CA, USA) and sequenced. The sequencing was carried out using a BigDye Terminator v1.1 Cycle Sequencing Kit (Applied Biosystems, Foster City, CA, USA). Unincorporated dye terminators were removed using a DyeEx 2.0 Spin Kit (Qiagen), and the reactions were run on an ABI PRISM 3100-Avant Genetic Analyzer (Applied Biosystems). Each PCR product was sequenced at least twice in both directions using the forward and reverse PCR primers.

Sequence data were analyzed using Sequencing Analysis Software 5.1 (Applied Biosystems) and SeqScape v.2.1.1 (Applied Biosystems). The individual gene sequences of each virus isolate were assembled into one continuous sequence using SeqMan Pro v.8.0.2 from the DNASTAR Lasergene 8 application package (DNASTAR Inc.). Multiple sequence alignments of the continuous sequences were done with ClustalX 1.81 [46] and edited with GeneDoc version 2.6.02 [47]. Sequence pair percent identity values were calculated using the MegAlign program from the DNASTAR Lasergene 8 application package. Maximum parsimony phylogenetic analysis was performed with Mega 4.1 software [48]. The reliability of the phylogeny was assessed by bootstrapping.

Table 2 Primers used to amplify different ranavirus genes

\begin{tabular}{|c|c|c|c|c|c|}
\hline Primer & Target & Primer position & Nucleotide Sequence $\left(5^{\prime}-3^{\prime}\right)$ & Amplicon size & Reference \\
\hline$* \mathrm{MCP}-\mathrm{AF}$ & $\mathrm{MCP}$ & 97279-97299 & ССТCCAAAGAGAGCGATATGC & 626 & $\mathrm{U} 36913^{\mathrm{a}}$ \\
\hline$*$ MCP-AR & & 97904-97887 & AAGAATGGGAGGGGAAGA & & \\
\hline$* \mathrm{MCP}-\mathrm{BF}$ & $\mathrm{MCP}$ & $97813-97830$ & ACCAGCGATCTCATCAAC & 548 & $\mathrm{U} 36913^{\mathrm{a}}$ \\
\hline *MCP-BR & & $98360-98341$ & AGCGCTGGCTCCAGGACCGT & & \\
\hline MCP-5 & $\mathrm{MCP}$ & 98244-98263 & CGCAGTCAAGGCCTTGATGT & 585 & Hyatt et al. [37] \\
\hline MCP-6R & & $98828-98807$ & AAAGACCCGTTTTGCAGCAAAC & & \\
\hline DNApol-F & DNApol & $67188-67208$ & GTGTAYCAGTGGTTTTGCGAC & 560 & Holopainen et al. [26] \\
\hline DNApol-R & & $67747-67728$ & TCGTCTCCGGGYCTGTCTTT & & \\
\hline *RNase III-F & RNase III & $88858-88836$ & GAGGCKCTGGAGATYGTGGGSGA & 717 & AY548484 ${ }^{\mathrm{b}}, \mathrm{AY} 666015^{\mathrm{c}}, \mathrm{AF} 389451^{\mathrm{d}}$ \\
\hline *RNase III-R & & $88142-88159$ & CCCRCTRCCCTCVACRAC & & \\
\hline$* \mathrm{RNR}-\mathrm{AF}$ & RNR- $\alpha$ & $43729-43748$ & CTGCCCATCTCKTGCTTTCT & 806 & AY548484 ${ }^{\mathrm{b}}, \mathrm{AY} 666015^{\mathrm{c}}$ \\
\hline$*$ RNR-AR & & $44534-44513$ & CTGGCCCASCCCATKGCGCCCA & & \\
\hline$*$ RNR-BF & RNR- $\beta$ & $78029-78012$ & AGGTGTRCCRGGGYCGTA & 646 & AY548484 ${ }^{\mathrm{b}}, \mathrm{AY} 666015^{\mathrm{c}}$ \\
\hline$* \mathrm{RNR}-\mathrm{BR}$ & & 77384-77403 & GACGCTCCAYTCGACCACTT & & \\
\hline
\end{tabular}

The position of the primer is presented relative to FV3 genome AY548484. New primers used in this study are marked with an asterisk. The reference for each primer is either the original publication or the GenBank accession number for previously published sequences based on which the primers were designed

$\mathrm{Y}=\mathrm{C} / \mathrm{T}, \mathrm{K}=\mathrm{G} / \mathrm{T}, \mathrm{S}=\mathrm{C} / \mathrm{G}, \mathrm{R}=\mathrm{A} / \mathrm{G}, \mathrm{V}=\mathrm{A} / \mathrm{C} / \mathrm{G}$

${ }^{\mathrm{a}}$ Mao et al. [54], ${ }^{\mathrm{b}} \mathrm{Tan}$ et al. [51], ${ }^{\mathrm{c}} \mathrm{Tsai}$ et al. [58], ${ }^{\mathrm{d}} \mathrm{He}$ et al. [56] 
Experimental challenge of rainbow trout

The pathogenicity of the panel of ranavirus isolates was tested by experimental challenge of rainbow trout fry. The fry (average weight $1.5 \mathrm{~g}$ ) were obtained from a certified virus-free hatchery, Rønhøjgård in Denmark, and were screened for viral, parasitic and bacterial infections prior to challenge. The challenges were carried out at the challenge facilities of DTU in Århus. Fish were kept in 10-1 tanks with 50 animals per tank in $15^{\circ} \mathrm{C}$ water with constant aeration and a flow-through system. Three challenge treatments were tested: Intraperitoneal inoculation of $50 \mu \mathrm{l}$ viral suspension $\left(10^{4} \mathrm{TCID}_{50}\right)$ per fish, bath exposure at a high dose $\left(10^{4} \mathrm{TCID}_{50} / \mathrm{ml}\right)$ and at a lower dose $\left(10^{3}\right.$ $\mathrm{TCID}_{50} / \mathrm{ml}$ ) for $2 \mathrm{~h}$. The two bath treatments were tested in duplicate. Nine ranavirus isolates in the panel described above were tested in the three treatments. A negative and positive control, consisting of cell culture medium and the viral haemorrhagic septicaemia (VHS) virus strain DK3592B [49], respectively, were included in each treatment. Fish were tranquilised with benzocaine prior to i.p. inoculation. For bath exposure, the water levels were lowered, and circulation was stopped for $2 \mathrm{~h}$ whilst aeration was maintained. Fish were monitored and fed twice daily. Mortality was recorded daily, and moribund or dead fish were collected and frozen at $20^{\circ} \mathrm{C}$ for virological examination by standard virological procedures [50] at the end of each trial. Five fish were collected from each tank on day seven post-challenge and examined individually. On day 28, a pool of five fish from each tank was likewise examined.

\section{Results}

The ranavirus isolate from turbot was obtained from 3 of 10 samples of pooled organ material of apparently healthy turbot fry originating from a Danish turbot aquaculture facility. No other pathogens were detected. The material was inoculated onto BF-2 and SSN-1 cells and incubated at both 15 and $21^{\circ} \mathrm{C}$. Cytopathic effect (CPE) was observed in both cell lines after 7 days and was most prominent at $21^{\circ} \mathrm{C}$. Cytopathic effect was characterised by small foci of rounded cells in a cobweb-like matrix. The CPE developed into plaques with rounded cells along the edges. At total $\mathrm{CPE}$, the cells had all detached from the culture surface. The isolate tested negative for IPN, VHS and infectious haematopoietic necrosis virus (IHNV) in ELISA. Infected cultures of EPC cells grown on coverslips stained positive in IFAT using rabbit antisera against the ranaviruses, CodV, BIV and EHNV. There was no cross-reaction with antisera against RSIV, IPNV or LTR (Table 3).

Rabbit F61 reacted strongly in IFAT with homologous and heterologous ranaviruses at dilution 1:800-1:1,000, while the staining with F62 was less pronounced (not shown). Differentiation of the isolates in the panel was not possible in IFAT due to complete cross-reaction with all of the ranavirus antisera tested (Table 3). Positive staining was observed for all combinations, although some reacted more strongly than others. The monoclonal antisera produced against RSIV did not produce any staining when tested against the isolates in the panel, and neither did the antisera against IPNV or LTR. The staining of the isolates with antibodies against EHNV is shown in Fig. 1. Positive

Table 3 Immunofluorescent staining of a panel of 11 iridoviruses with rabbit antisera produced against 8 different iridovirus isolates. A monoclonal antibody against RSIV and rabbit antisera against IPNV and lake trout rhabdovirus were tested as well

\begin{tabular}{|c|c|c|c|c|c|c|c|c|c|c|c|}
\hline \multirow[t]{2}{*}{ Virus } & \multicolumn{10}{|c|}{ Polyclonal antiserum against } & \multirow{2}{*}{$\begin{array}{l}\text { MAb } \\
\text { RSIV }\end{array}$} \\
\hline & BIV & CodV & ECV It & ECV Fr & EHNV & ESV & PPIV & $\mathrm{Rmax}$ & $I P N V$ & L.trout & \\
\hline BIV & + & + & + & + & + & + & + & + & $N D$ & $N D$ & $\mathrm{Neg}$ \\
\hline CodV & + & + & + & + & + & + & + & + & $N D$ & $N D$ & $\mathrm{Neg}$ \\
\hline ECV It & + & + & + & + & + & + & + & + & $N D$ & $N D$ & $\mathrm{Neg}$ \\
\hline ECV Fr & + & + & + & + & + & + & + & + & $N D$ & $N D$ & $\mathrm{Neg}$ \\
\hline EHNV & + & + & + & + & + & + & + & + & $N D$ & $N D$ & $\mathrm{Neg}$ \\
\hline ESV & + & + & + & + & + & + & + & + & $N D$ & $N D$ & $\mathrm{Neg}$ \\
\hline FV3 & + & + & + & + & + & + & + & + & $N D$ & $N D$ & $\mathrm{Neg}$ \\
\hline PPIV & + & + & + & + & + & + & + & + & $N D$ & $N D$ & $\mathrm{Neg}$ \\
\hline REV 282/I02 & ND & ND & ND & ND & + & ND & ND & ND & $N D$ & $N D$ & $\mathrm{Neg}$ \\
\hline$R \max$ & + & + & + & + & + & + & + & + & $N D$ & $N D$ & $\mathrm{Neg}$ \\
\hline SERV & ND & ND & ND & ND & + & ND & ND & ND & $N D$ & $N D$ & $\mathrm{Neg}$ \\
\hline$I P N V$ & $\mathrm{Neg}$ & $\mathrm{Neg}$ & $\mathrm{Neg}$ & $\mathrm{Neg}$ & $\mathrm{Neg}$ & $\mathrm{Neg}$ & $\mathrm{Neg}$ & $\mathrm{Neg}$ & + & $\mathrm{Neg}$ & $\mathrm{Neg}$ \\
\hline L. Trout & $\mathrm{Neg}$ & $\mathrm{Neg}$ & $\mathrm{Neg}$ & $\mathrm{Neg}$ & $\mathrm{Neg}$ & $\mathrm{Neg}$ & $\mathrm{Neg}$ & $\mathrm{Neg}$ & $\mathrm{Neg}$ & + & $\mathrm{Neg}$ \\
\hline
\end{tabular}

Negative controls are italisized. Neg no staining, $N D$ not done, + indicates positive reaction 
Fig. 1 IFAT staining of ranavirus infected EPC cells with antibodies against EHNV. Cytoplasms of the infected cells are stained with fluorescein (green). Virus isolates used in the infection: $1 \mathrm{BIV}, 2 \mathrm{CodV}$, $3 \mathrm{ECV}, 4 \mathrm{EHNV}, 5 \mathrm{ESV}$, 6 FV3, 7 PPIV, 8 REV 282/I02, 9 Rmax, 10 SERV. Pictures were taken with $400 \times$ magnification
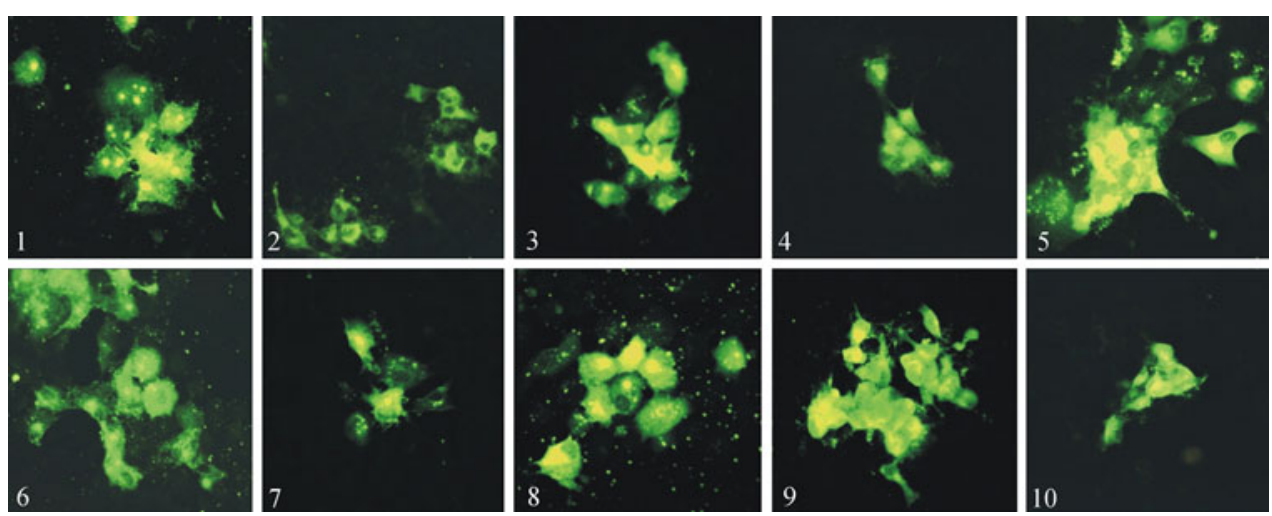

Table 4 GenBank accession numbers of the sequences used in the analyses

\begin{tabular}{|c|c|c|c|c|c|}
\hline Virus & $\mathrm{MCP}$ & DNApol & RNase III & RNR- $\alpha$ & RNR- $\beta$ \\
\hline BIV & FJ358613 ${ }^{\mathrm{a}}(58.9 \%)$ & FJ374280a $(62 \%)$ & GU391273* (58.1\%) & GU391286* (60.6\%) & GU391264* (55.8\%) \\
\hline CodV & GU391284* (59.3\%) & GU391282* $(62 \%)$ & GU391274* (58.3\%) & GU391287* (61.5\%) & GU391265* (55.9\%) \\
\hline $\mathrm{ECV}$ & FJ358608 ${ }^{\mathrm{a}}(60.3 \%)$ & FJ374277 $(62.6 \%)$ & GU391275* (59.2\%) & GU391288* (61.5\%) & GU391266* (55.9\%) \\
\hline EHNV & AY $187045^{\mathrm{b}}(60.0 \%)$ & FJ374274 ${ }^{\mathrm{a}}(62.2 \%)$ & GU391276* (59.8\%) & GU391289* (61.1\%) & GU391267* (56.3\%) \\
\hline ESV & FJ358609 $(60.3 \%)$ & FJ374278 $(62.2 \%)$ & GU391277* (59.3\%) & GU391290* (61.5\%) & GU391268* (55.9\%) \\
\hline FV3 & FJ459783 ${ }^{\mathrm{a}}(59.1 \%)$ & AY548484 $(62.0 \%)$ & AY548484 $(58.3 \%)$ & AY548484 $(60.6 \%)$ & AY548484 $(55.8 \%)$ \\
\hline PPIV & FJ358610 $(59.7 \%)$ & FJ374276 ${ }^{\mathrm{a}}(62.0 \%)$ & GU391278* (58.6\%) & GU391292* (61.1\%) & GU391269* $(55.8 \%)$ \\
\hline REV282/I02 & FJ358611 ${ }^{\mathrm{a}}(59.5 \%)$ & FJ374275 $(61.5 \%)$ & GU391280* (58.4\%) & GU391293* (60.9\%) & GU391271* (55.8\%) \\
\hline $\operatorname{Rmax}$ & GU391285* (59.3\%) & GU391283* (61.8\%) & GU391279* (58.3\%) & GU391291* (61.3\%) & GU391270* (55.6\%) \\
\hline SERV & FJ358612 ${ }^{\mathrm{a}}(60.5 \%)$ & FJ $374279^{\mathrm{a}}(63.2 \%)$ & GU391281* (60.4\%) & GU391294* (61.8\%) & GU391272* $(55.9 \%)$ \\
\hline TFV & $\mathrm{AF} 389451^{\mathrm{d}}(59.1 \%)$ & $\mathrm{AF} 389451^{\mathrm{d}}(62.4 \%)$ & AF389451 ${ }^{\mathrm{d}}(57.5 \%)$ & AF389451 ${ }^{\mathrm{d}}(61.1 \%)$ & AF389451 ${ }^{\mathrm{d}}(55.6 \%)$ \\
\hline SGIV & NC_006549 $(50.6 \%)$ & NC_006549 $(48.7 \%)$ & NC_006549 $(49.2 \%)$ & NC_006549 $(52.7 \%)$ & NC_006549 $(48.6 \%)$ \\
\hline GIV & AY666015 $5^{\mathrm{f}}(50.6 \%)$ & AY666015 $(49.7 \%)$ & AY666015 ${ }^{\mathrm{f}}(49.1 \%)$ & AY666015 ${ }^{\mathrm{f}}(52.9 \%)$ & AY666015 $(48.8 \%)$ \\
\hline
\end{tabular}

Sequences marked with an asterisk (*) were obtained in this study. GC contents of the sequences are given in brackets

${ }^{\mathrm{a}}$ Holopainen et al. [26], ${ }^{\mathrm{b}}$ Marsh et al. [53], ${ }^{\mathrm{c}}$ Tan et al. [51], ${ }^{\mathrm{d}} \mathrm{He}$ et al. [56], ${ }^{\mathrm{e}}$ Song et al. [57], ${ }^{\mathrm{f}} \mathrm{Tsai}$ et al. [58]

staining was detected in the cytoplasm of infected EPC cells with all of the virus isolates studied.

The complete MCP gene and partial DNApol, RNase III, RNR- $\alpha$ and RNR- $\beta$ genes were successfully amplified from both CodV and Rmax. Based on sequence analysis, the lengths of the amplified gene fragments corresponded to the predicted amplicon sizes estimated from the FV3 genome [51] (GenBank AY548484). The MCP gene sequences of CodV and Rmax were obtained in three overlapping fragments, and the length of the open reading frame (ORF), 1,392 bp, was identical with the other ranaviruses studied. In addition, the partial RNase III, RNR- $\alpha$ and RNR- $\beta$ genes of BIV, EHNV, ECV (It), ESV, FV3, PPIV, REV282/I02 and SERV were amplified and sequenced. The complete genome of FV3 has been published earlier [51] and the RNase III, RNR- $\alpha$ and RNR- $\beta$ sequences of FV3 obtained in this study matched the published data. For BIV, EHNV, ECV (It), ESV, PPIV, REV282/I02 and SERV, there were no previously published sequence data for the RNase III, RNR- $\alpha$ and RNR- $\beta$ genes. The novel MCP, DNApol, RNase III, RNR- $\alpha$ and RNR- $\beta$ gene sequences obtained from the isolates studied were deposited into the GenBank database (Table 4).

In order to study the phylogenetic relationships of the virus isolates, the individual gene sequences of each virus isolate were assembled into one continuous sequence. The order of the gene sequences was arranged to match the gene order of the FV3 genome [51] (AY548484): RNR- $\alpha$, DNApol, RNR- $\beta$, RNase III and MCP. The sequences of different gene regions were concatenated according to the ORFs of each gene; missing nucleotides in the junction of gene fragments were coded into the sequence in order to maintain the correct reading frame. Previously published sequences of the virus isolates studied were used in the sequence analysis (Table 4). The length of the concatenated sequence was $3,959 \mathrm{bp}$ in all 10 virus isolates studied. Previously published sequences of three other ranaviruses, tiger frog virus (TFV), Singapore grouper iridovirus (SGIV) and grouper iridovirus (GIV), were also included into the maximum parsimony phylogenetic 
Table 5 Ranavirus sequence pair percent identity values based on the concatenated nucleotide (3,959 bp) and amino acid (1,317 aa) sequences of the RNR- $\alpha$, DNApol, RNR- $\beta$, RNase III and MCP genes

\begin{tabular}{|c|c|c|c|c|c|c|c|c|c|c|c|c|c|}
\hline & BIV & CodV & $\mathrm{ECV}$ & EHNV & ESV & FV3 & PPIV & $\begin{array}{l}\text { REV } \\
282 / \mathrm{I} 02\end{array}$ & $R \max$ & SERV & TFV & GIV & SGIV \\
\hline BIV & & 97.6 & 97.7 & 98.2 & 97.7 & 98.8 & 98.6 & 98.4 & 97.5 & 95.1 & 98.5 & 65.3 & 64.8 \\
\hline CodV & 96.9 & & 98.3 & 98.6 & 98.3 & 97.6 & 98.2 & 98.0 & 99.7 & 95.4 & 97.6 & 65.2 & 64.8 \\
\hline $\mathrm{ECV}$ & 97.4 & 97.3 & & 99.0 & 100 & 97.8 & 98.4 & 98.2 & 98.3 & 96.2 & 97.7 & 65.5 & 65.0 \\
\hline EHNV & 98.1 & 97.7 & 98.4 & & 99.1 & 98.2 & 98.8 & 98.6 & 98.6 & 96.1 & 98.1 & 65.1 & 64.8 \\
\hline ESV & 97.4 & 97.3 & 100 & 98.4 & & 97.8 & 98.4 & 98.2 & 98.3 & 96.2 & 97.7 & 65.4 & 65.0 \\
\hline FV3 & 99.2 & 96.8 & 97.3 & 97.9 & 97.3 & & 98.6 & 98.4 & 97.5 & 95.1 & 98.5 & 65.3 & 64.8 \\
\hline PPIV & 98.9 & 97.6 & 98.0 & 98.7 & 98.0 & 98.6 & & 99.2 & 98.1 & 95.5 & 98.5 & 65.4 & 65.0 \\
\hline REV282/I02 & 98.4 & 97.3 & 97.7 & 98.4 & 97.7 & 98.3 & 99.0 & & 97.9 & 95.3 & 98.2 & 65.3 & 64.9 \\
\hline $\operatorname{Rmax}$ & 97.1 & 99.5 & 97.4 & 97.8 & 97.4 & 97.0 & 97.7 & 97.4 & & 95.4 & 97.5 & 65.3 & 64.9 \\
\hline SERV & 95.9 & 95.7 & 96.8 & 96.5 & 96.8 & 95.9 & 96.3 & 96.0 & 96.0 & & 94.9 & 65.6 & 65.2 \\
\hline TFV & 98.6 & 96.6 & 97.0 & 97.7 & 97.0 & 98.5 & 98.3 & 97.9 & 96.8 & 95.6 & & 65.2 & 64.8 \\
\hline GIV & 67.8 & 67.5 & 67.8 & 67.3 & 67.8 & 67.5 & 67.7 & 67.5 & 67.6 & 67.5 & 67.5 & & 98.2 \\
\hline SGIV & 67.8 & 67.5 & 67.6 & 67.2 & 67.6 & 67.6 & 67.8 & 67.5 & 67.6 & 67.5 & 67.5 & 98.9 & \\
\hline
\end{tabular}

Nucleotide sequence identity values are presented in the upper diagonal, and amino acid identity values in the lower diagonal. The GenBank accession numbers of the sequences used in the analyses are presented in Table 4

analysis as well as into the nucleotide (nt) and amino acid (aa) sequence identity comparisons. The GC content of all of the sequences analysed varied between $48.6 \%$ in RNR- $\beta$ of SGIV and $63.2 \%$ in DNApol of SERV.

The nt and aa sequence pair percent identity values of CodV and Rmax compared with other ranavirus sequences are presented in Table 5. Based on the sequences obtained for the RNR- $\alpha$, DNApol, RNR- $\beta$, RNase III and MCP genes, the overall nt identity among the 10 ranavirus isolates studied was between 95.1 and $100 \%$. ECV and ESV had identical aa sequences and only one nt difference in the entire concatenated sequence (in RNR- $\beta$ ). SERV was the most divergent of the isolates studied. CodV and Rmax had $13 \mathrm{nt}$ and 6 aa differences in the entire concatenated sequence: $2 \mathrm{nt}$ differences and 1 aa difference in RNR- $\alpha$, $5 \mathrm{nt}$ and 3 aa in DNApol, $2 \mathrm{nt}$ and 1 aa in RNR- $\beta, 2 \mathrm{nt}$ and 1 aa in RNase III and 2 nt and no aa differences in MCP. The overall nt sequence identity between CodV and Rmax was $99.7 \%$; the aa sequence identity was $99.5 \%$. The closest relatives to Rmax and CodV were EHNV, with 98.6\%, and ECV and ESV, with 98.3\% nt sequence identity. The same affinity can be seen in the results of the maximum parsimony phylogenetic analysis; Rmax and CodV cluster closely with EHNV (Fig. 2).

Mortality in experimental tanks was low (max 2/50 fish per tank) and did not exceed that recorded in the placebo treatments. The positive-control tanks experienced $70 \%$ accumulated mortality by day 28 , and VHS was isolated from dead fish. Of the fish collected at day 7 from the different treatments, one isolation was made from an individual fish in the bath treatment with EHNV, and two other isolations were made from individual fish inoculated with FV3 and ESV, respectively. At day 28 , no virus was isolated from the pooled samples collected from each treatment. From a pool of the dead fish from the third week of the experiment, virus was isolated from fish that had been inoculated with ESV and EHNV. Virus was not isolated from fish that died during weeks 2 and 4 . All viruses isolated from challenged fish were confirmed to be ranaviruses in IFAT using anti-EHNV antisera. Histopathological examination of 50 fish (10 from 5 tanks) did not reveal any pathological changes.

\section{Discussion}

Currently, EHNV is the only ranavirus listed by the OIE as notifiable for fish. In addition to EHNV, there are also other known pathogenic ranavirus isolates, e.g. ESV and ECV [16-18]. The common denominator stringing these events together is the relatively high water temperature under which the fish were cultured. Several other ranavirus isolations have been made, many of which appear to be haphazard isolations from symptomless fish, indicating that ranavirus isolates are not always virulent [1]. The panel of isolates investigated here contains isolates from outbreaks, from routine survey of apparently healthy fish, and three amphibian isolates: FV3, the reference strain for ranaviruses, BIV and REV 282/I02. The objective was to compare two Danish isolates to a panel of ranavirus in terms of their reactivity in IFAT, sequence of MCP, DNApol, RNase III, RNR- $\alpha$ and RNR- $\beta$ and relative pathogenicity to rainbow trout under experimental challenge conditions. 


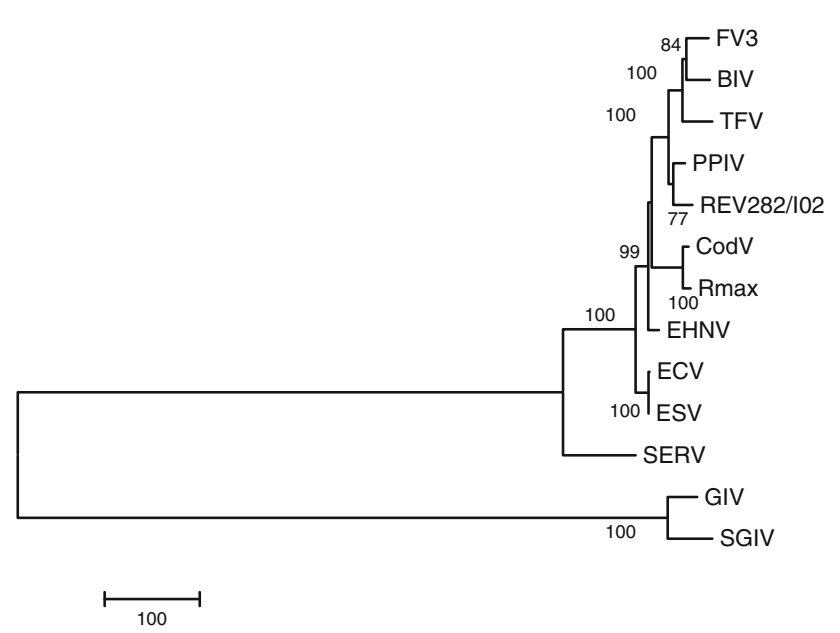

Fig. 2 Maximum parsimony analysis of the concatenated nucleotide sequences $(3,959 \mathrm{bp})$ of RNR- $\alpha$, DNApol, RNR- $\beta$, RNase III and MCP genes of ranaviruses. Numbers at the nodes of the tree indicate bootstrap values of 1,000 replicates; values under 70 are not shown. Scale bar indicates 100 nucleotide substitutions. The GenBank accession numbers of sequences used in the analysis are presented in Table 4

Both CodV and Rmax reacted with all of the polyclonal antisera against the various ranavirus but not the monoclonal antiserum against RSIV and the negative-control antisera. The high degree of serological cross-reaction between ranavirus isolates renders IFAT based on polyclonal antisera a suitable technique for fast identification of ranaviruses [34]. The technique does not allow for separating isolates into notifiable and non-notifiable or into pathogenic versus non-pathogenic groups. A panel of specific monoclonal antibodies could be a possible alternative to achieve this, and by implementation in an ELISA, this would be an easy, fast and reliable technique to differentiate these isolates. This is, of course, assuming that sufficient epitope differences exist among the isolates to produce differentiating antibodies. Alternatively, PCR may lead the way towards differential diagnosis with the design of specific primers to differentiate according to pathogenicity of strains. A real-time PCR method has been developed to differentiate between Australian and European ranavirus isolates [52]. Other methods such as restriction enzyme analysis (REA) can also differentiate strains [26-53], but is not commonly implemented in routine diagnostic laboratories in Europe.

In addition to PCR and REA, differentiation of ranaviruses can be accomplished by sequencing a genomic region [26, 37, 54]. To date, five ranavirus genomes have been completely sequenced: FV3 [51], Ambystoma tigrinum virus (ATV) [55], TFV [56], SGIV [57] and GIV [58]. Complete or partial sequences of specific viral genes, e.g. $\mathrm{MCP}$ and DNApol, have been reported for several ranaviruses isolated from both amphibian and fish species
[5, 26, 37, 53, 54, 58-64]. Ranaviruses are a genetically homogenous group, with only a few divergent isolates: GIV, SGIV, doctorfish virus (DFV) and guppy virus 6 (GV6) [26, 37, 57, 59, 63, 65]. In this study, novel sequence data from all ten viruses studied, including the two Danish isolates CodV and Rmax, were obtained. The sequence data from five different gene regions of each virus isolate were combined and analysed as a concatenated sequence. Combining data, e.g. sequences from several genes, reduces the sampling variation in the phylogenetic analysis and provides more accurate phylogeny [66]. Based on the sequences analysed, differentiation of the isolates studied was possible, even though ECV and ESV differed by only one nucleotide in the entire concatenated sequence region. CodV and Rmax were very closely related to each other, and in the maximum parsimony phylogenetic analysis, they clustered together with EHNV.

EHNV has repeatedly been diagnosed in cultured rainbow trout in Australia with a low infectivity rate and high case mortality [67]. None of the nine isolates in the current study proved virulent to rainbow trout under the experimental conditions applied $\left(15^{\circ} \mathrm{C}\right.$ water temperature and both bath and i.p. exposure) even though virus was isolated from dead fish in the third week of the experiment, indicating that infection in a few cases did become established. Challenge trials with the cod and turbot ranavirus isolates in cod and turbot could reveal a different level of pathogenicity than what was observed here.

Temperature seems to be a contributing factor in the virulence of these viruses, affecting viral growth in vitro [21] and the immune defence of fish [68]. Whittington and Reddacliff [69] found that rainbow trout were not susceptible to EHNV infection by bath, but they could reproduce the disease by i.p. inoculation with $10^{5.6}$ TCID50 at water temperatures from 8 to $21^{\circ} \mathrm{C}$. The incubation period increased with decreasing temperature and increased to 32 days at $8-10^{\circ} \mathrm{C}$. Possibly, the experimental infection in this study induced only subclinical infection at $15^{\circ} \mathrm{C}$ in the majority of the population, or infection was not established. Persistent infection with EHNV in i.p.-inoculated rainbow trout was also detected by Whittington et al. [67] in a subclinically affected rainbow trout 63 days after exposure, which renders rainbow trout efficient vectors for an infection, especially when transferred from colder to warmer climates. Challenge trials with ESV in sheatfish cultured at $24^{\circ} \mathrm{C}$ resulted in $100 \%$ mortality 8 days after bath challenge and 11 days after exposure via co-habitation [70]. The pathogenicity of ranavirus isolates on commonly cultured warm-water species of European fish could be detrimental and should be tested.

Brunner et al. [71] found that the infectious dose and the genetic background of the experimental animals as well as their life-history stage influenced the virulence of ranavirus 
infections in tiger salamander (Ambystoma tigrinum) under experimental conditions. Possibly, the doses we used in this study combined with the relatively low temperatures could have "concealed" the virulence of the isolates tested. Alternatively, the strain of rainbow trout used may be resistant to the isolates in the panel, or the experimental conditions were somehow not conducive to establishing an infection. Our findings are in accordance with other challenge studies of European stock of rainbow trout with ranavirus [72, 73], in which it was found that rainbow trout and red-fin perch (Perca fluviatilis) cultured under northern European conditions are relatively well protected against ranaviruses due to the low temperatures at which they are normally cultured.

Under the challenge conditions applied in this study, none of the isolates appeared to be highly pathogenic to rainbow trout. The results of IFAT and sequencing investigations firmly placed both Danish isolates, CodV and Rmax, within the genus Ranavirus, and we suggest the name Ranavirus maxima for the turbot isolate.

Acknowledgments The present work was partly funded by the 6th framework program of European Union contract number SSPE-CT2005-006459, project RANA. Drs. Ahne, Bovo, Hyatt, de Kinkelin, Larsen, Nakajima, Owens and Whittington are acknowledged for providing iridovirus strains and antibodies. Thanks are due to all our technicians, but especially Nicole Nicolajsen.

Conflict of interest statement The authors declare that they have no conflict of interest.

\section{References}

1. Chinchar VG, Essbauer S, He JG, Hyatt AD, Miyazaki T, Seligy V, Williams T (2005) Family Iridoviridae. In: Fauguet CM, Mayo MA, Maniloff J, desselberger U, Ball LA (eds) Virus Taxonomy. Eighth report of the International Committee on the taxonomy of Viruses. Elsevier Academic Press, London, pp 145-162

2. Goorha R (1982) Frog virus 3 DNA replication occurs in two stages. J Virol Aug 43(2):519-528

3. Jancovich JK, Davidson EW, Morado JF, Jacobs BL, Collins JP (1997) Isolation of a lethal virus from the endangered tiger salamander Ambystoma tigrinum stebbinsi. Dis Aquat Organ 31:161-167

4. Zupanovic Z, Musso C, Lopez G, Louriero CL, Hyatt AD, Hengstberger S, Robinson AJ (1998) Isolation and characterization of iridoviruses from the giant toad Bufo marinus in Venezuela. Dis Aquat Organ 33:1-9

5. Zhang QY, Xiao F, Li ZQ, Gui JF, Mao J, Chinchar VG (2001) Characterisation of an iridovirus from the cultured pig frog Rana grylio with lethal syndrome. Dis Aquat Organ 48:27-36

6. Weng SP, He JG, Wang XH, Lu L, Deng M, Chan SM (2002) Outbreaks of an iridovirus disease in cultured tiger frog, Rana tigrina rugulosa, in southern China. J Fish Dis 25:423-427

7. Westhouse RA, Jacobson ER, Harris RK, Winter KR, Homer BL (1996) Respiratory and pharyngoesophageal iridovirus infection in a gopher tortoise (Gopherus polyphemus). J Wildl Dis 32:682686
8. Marschang RE, Becher P, Posthaus H, Wild P, Thiel HJ, MullerBoblies U, Kaleta EF, Bacciarini LN (1999) Isolation and characterisation of an iridovirus from Hermann's tortoise (Testudi hermanni). Arch Virol 144:1909-1922

9. Chen ZX, Zheng JC, Jiang YL (1999) A new iridovirus isolated from soft-shelled turtle. Virus Res 63:147-151

10. Just F, Essbauer S, Ahne W, Blahak S (2001) Occurrence of an Invertebrate Iridescent-like virus (Iridoviridae) in Reptiles. J Vet Med B48:685-694

11. Drury SEN, Gough RE, Calvert I (2002) Detection and isolation of an iridovirus from chameleons (Chamaeleo quadricornis and Chamaeleo hoehnelli) in the United Kingdom. Vet Rec 150:451452

12. Hyatt AD, Williamson M, Coupar BEH, Middleton D, Hengstberger SG, Gould AR, Selleck P, Wise TG, Kattenbelt J, Cunningham AA, Lee J (2002) First identification of a ranavirus from green pythons (Chondropython viridis). J Wildl Dis 38(2):239-252

13. Langdon JS, Humphrey JD, Williams LM, Hyatt AD, Westbury HA (1986) First virus isolation from Australian fish: an iridovirus-like pathogen from redfin perch, Perca fluviatilis L. J Fish Dis 9:263-268

14. Langdon JS, Humphrey JD (1987) Epizootic haematopoietic necrosis, a new viral disease in redfin perch, Perca fluviatilis L., in Australia. J Fish Dis 10:289-297

15. Langdon JS, Humphrey JD, Williams LM (1988) Outbreaks of an EHNV-like iridovirus in cultured rainbow trout, Salmo gairdneri Richardson, in Australia. J Fish Dis 11:93-96

16. Ahne W, Schlotfeldt HJ, Thomsen I (1989) Fish viruses: Isolation of an icosahedral cytoplasmic deoxyribovirus from sheatfish (Siluris glanis). J Vet Med B 36:333-336

17. Pozet F, Morand M, Moussa A, Torhy C, de Kinkelin P (1992) Isolation and preliminary characterisation of a pathogenic icosahedral deoxyribovirus from the catfish Ictalurus melas. Dis Aquat Organ 14:35-42

18. Bovo G, Comuzi M, De Mas S, Ceschia G, Giorgetti G, Giacometti P, Cappellozza E (1993) Isolamento di un agente virale irido-like da pesce gatto (Ictalurus melas) dallevamento. Bollettino Societa Italiana di Patologia Ittica 11:3-10

19. Tapiovaara H, Olesen NJ, Lindén J, Rimaila-Pärnänen E, von Bonsdorff C-H (1998) Isolation and characterization of an iridotype virus from pike-perch (Stizostedion lucioperca). Dis Aquat Organ 32:185-193

20. Bang Jensen B, Ersbøll AK, Ariel E (2009) Susceptibility of Pike Esox lucius to a panel of ranavirus isolates. Dis Aquat Org 83:169-179

21. Granoff A, Came PE, Rafferty KA (1965) The isolation and properties of viruses from Rana pipiens: Their possible relationship to the renal adenocarcinoma of the leopard frog. Ann NY Acad Sci 126:237-255

22. Speare R, Smith JR (1992) An iridovirus-like agent isolated from the borrowing frog, Lymnodynastes ornatus in northern Australia. Dis Aquat Org 14:51-57

23. Cullen BR, Owens L (2002) Experimental challenge and clinical cases of Bohle irodovirus (BIV) in native Australian anurans. Dis Aquat Org 49:83-92

24. Moody NJG, Owens L (1994) Experimantal demonstration of the pathogenicity of a frog virus, Bohle iridovirus, for a fish species, barramundi Lates calcarifer. Dis Aquat Organ 18:95-102

25. Ariel E, Owens L (1997) Epizootic mortalities in tilapia (Oreochromis mossambicus). Dis Aquat Org 29:1-6

26. Holopainen R, Ohlemeyer S, Schütze H, Bergmann SM, Tapiovaara H (2009) Ranavirus phylogeny and differentiation based on major capsid protein, DNA polymerase and neurofilament triplet H1-like protein genes. Dis Aquat Org 85:81-91

27. Cunningham AA, Langton TES, Bennett PM, Lewin JF, Drury SEN, Gough RE, MacGregor SK (1996) Pathological and 
microbiological findings from incidents of unusual mortality of the common frog (Rana temporaria). Philos Trans R Soc Lond B 351:1539-1557

28. Hoser R (1996) The frog decline in Australia. The reptilian magazine 4(3): 19-25

29. Daszak P, Berger L, Cunningham AA, Hyatt AD, Green DE, Speare R (1999) Emerging infectious diseases and amphibian population declines. Emerg Infect Dis 5(6):735-748

30. Jensen NJ, Bloch B, Larsen JL (1979) A preliminary virological report. Nordisk Veterinaer 31:436-442

31. Bloch B, Larsen JL (1993) An iridovirus-like agent associated with systemic infection in cultured turbot Scophthalmus maximus fry in Denmark. Dis Aquat Organ 15:235-240

32. Shi C-Y, Wang Y-G, Yang S-L, Huang J, Wang Q-Y (2004) The first report of an iridovirus-like agent infection in farmed turbot, Scophthalmus maximus, in China. Aquaculture 236:11-25

33. Kim W-S, Oh M-J, Jung S-J, Kim Y-J, Kitamura S-I (2005) Characterization of an iridovirus detected from cultured turbot Scophthalmus maximus in Korea. Dis Aquat Organ 64:175-180

34. Hedrick RP, McDowell TS, Ahne W, Torhy C, de Kinkelin P (1992) Properties of thre iridovirus-like agents associated with systemic infections of fish. Dis Aquat Organ 13:203-209

35. Hengstberger SG, Hyatt A, Speare R, Coupar BEH (1993) Comparison of epizootic haematopoietic necrosis virus and Bohle iridovirus, recently isolated Australian iridoviruses. Dis Auqat Organ 15:93-107

36. Ahne W, Bearzotti M, Bremont M, Essbauer S (1998) Comparison of European piscine and amphibian iridoviruses with epizootic haematopoietic necrosis virus and frog virus 3. J Med Vet B 45:373-383

37. Hyatt AD, Gould AR, Zupanovic Z, Cunningham AA, Hengstberger S, Whittington RJ, Kattenbelt J, Coupar BEH (2000) Comparative studies of piscine and amphibian iridoviruses. Arch Virol 145:301-331

38. Wolf K, Gravel M, Malsberger RG (1966) Lymphocystis virus:isolation in a centrarchid fish cell line. Science 151:10041005

39. Frerichs GN, Rodger HD, Peric Z (1996) Cell culture isolation of piscine neuropathy nodavirus from juvenile sea bass Dicentrarchus labrax. J Gen Virol 77:2067-2071

40. Reed LJ, Muench H (1938) A simple method of estimation of 50\% endpoints. Am J Hyg 27:493-497

41. Olesen NJ, Lorenzen E, La Patra S (1999) Production of neutralizing antisera against viral haemorrhagic septicaemia (VHS) virus by intravenous injections of rabbits. J Aquat Anim Health 11:10-16

42. Jørgensen PEV, Olesen NJ, Ahne W, Lorenzen N (1989) SVCV and PFR viruses: serological examination of 22 isolates indicates close relationship between the two fish rhabdoviruses. In: Ahne W, Kurstak E (eds) Viruses of lower vertebrates. Springer, Berlin, pp 349-366

43. Jørgensen PEV, Grauballe PC (1971) Problems in the serological typing of IPN virus. Acta Vet Scand 12:145-147

44. Koski P, Hill BJ, Way K, Neuvonen E, Rintamäki P (1992) A rhabdovirus isolated from brown trout (Salmo trutta m. lacustris [L]) with lesions in parenchymatous organs. Bull Eur Ass Fish Pathol 12(5):177-180

45. Björklund HV, Olesen NJ, Jørgensen PEV (1994) Biophysical and serological characterization of rhabdovirus 903/87 isolated from European lake trout Salmo trutta lacustris. Dis Aquat Org 19:21-26

46. Thompson JD, Gibson TJ, Plewniak F, Jeanmougin F, Higgins DG (1997) The CLUSTAL_X windows interface: flexible strategies for multible sequence alignment aided by quality analysis tools. Nucleic Acid Res 25:4876-4882

47. Nicholas KB, Nicholas HB Jr, Deerfield DW II (1997) GeneDoc: analysis and visualization of genetic variation, EMBNEW.NEWS $4: 14$
48. Tamura K, Dudley J, Nei M, Kumar S (2007) MEGA4: Molecular Evolutionary Genetics Analysis (MEGA) Software version 4.0. Mol Biol Evol 24:1596-1599

49. Lorenzen N, Olesen NJ, Jørgensen PEV (1993) Antibody response to VHS virus proteins in rainbow trout. Fish and Shellfish Immunol 3:461-473

50. Anonymous (2001) Commission Decision of 22 February 2001. Laying down the sampling plans and diagnostic methods for the detection and confirmation of certain fish diseases and repealing Decision 92/532/EEC. 2001/183/EC. Off J Euro Commun L 067, 0065-0076.

51. Tan WG, Barkman TJ, Chinchar VG, Essani K (2004) Comparative genomic analyses of frog virus 3 , type species of the genus Ranavirus (family Iridoviridae). Virology 323:70-84

52. Pallister J, Gould A, Harrison D, Hyatt A, Jancovich J, Heine H (2007) Development of real-time PCR assays for the detection and differentiation of Australian and European ranaviruses. J Fish Dis 30:427-438

53. Marsh IB, Whittington RJ, O'Rourke B, Hyatt AD, Chisholm O (2002) Rapid differentiation of Australian, European and American ranaviruses based on variation in major capsid protein gene sequence. Mol Cell Probes 16:137-151

54. Mao J, Tham TN, Gentry GA, Aubertin A, Chinchar VG (1996) Cloning, sequence analysis, and expression of the major capsid protein of the iridovirus Frog virus 3. Virology 216:431-436

55. Jancovich JK, Mao J, Chinchar VG, Wyatt C, Case ST, Kumar S, Valente G, Subramanian S, Davidson EW, Collins JP, Jacobs BL (2003) Genomic sequence of a ranavirus (family Iridoviridae) associated with salamander mortalities in North America. Virology 316:90-103

56. He JG, Lü L, Deng M, He HH, Weng SP, Wang XH, Zhou SY, Long QX, Wang XZ, Chan SM (2002) Sequence analysis of the complete genome of an iridovirus isolated from the tiger frog. Virology 292:185-197

57. Song WJ, Qin QW, Qiu J, Huang CH, Wang F, Hew CL (2004) Functional genomics analysis of Singapore Grouper Iridovirus: Complete sequence determination and proteomic analysis. J Virol 78:12576-12590

58. Tsai CT, Ting JW, Wu MH, Wu MF, Guo IC, Chang CY (2005) Complete genome sequence of the grouper iridovirus and comparison of genomic organization with those of other iridoviruses. J Virol 79:2010-2023

59. Mao J, Hedrick RP, Chinchar VG (1997) Molecular characterization, sequence analysis, and taxonomic position of newly isolated fish iridoviruses. Virology 229:212-220

60. Mao J, Gree DE, Fellers G, Chinchar VG (1999) Molecular characterization of iridoviruses isolated from sympatric amphibians and fish. Virus Res 63:45-52

61. Mao J, Wang J, Chinchar GD, Chinchar VG (1999) Molecular characterization of a ranavirus isolated from largemouth bass Micropterus salmoides. Dis Aquat Org 37:107-114

62. Bollinger TK, Mao J, Schock D, Brigham RM, Chinchar VG (1999) Pathology, isolation, and preliminary molecular characterization of a novel iridovirus from tiger salamanders in Saskatchewan. J Wildl Dis 35:413-429

63. Qin QW, Chang SF, Ngoh-Lim GH, Gibson Kueh S, Shi C, Lam TJ (2003) Characterization of a novel ranavirus isolated from grouper Epinephelus tauvina. Dis Aquat Org 53:1-9

64. Greer AL, Berrill M, Wilson PJ (2005) Five Amphibian mortality events associated with ranavirus infection on south central Ontario, Canada. Dis Aquat Org 67:9-14

65. Eaton HE, Metcalf J, Penny E, Tcherepanov V, Upton C, Brunetti CR (2007) Comparative genomic analysis of the family Iridoviridae: re-annotating and defining the core set of iridovirus genes. Virol J 4:11 
66. Huelsenbeck JP, Bull JJ, Cunningham CW (1996) Combining data in phylogenetic analysis. TREE 11:152-158

67. Whittington RJ, Reddacliff LA, Marsh I, Kearns C, Zupanovic Z, Callinan RC (1999) Further observations on the epidemiology and spread of epizootic haematopoietic necrosis virus (EHNV) in farmed rainbow trout Oncorhynchus mykiss in southeastern Australia and a recommended sampling strategy for surveillance. Dis Aquat Organ 35:125-130

68. Le Morvan C, Troutaud D, Deschaux P (1998) Differential effects of temperature on specific and non-specific immune defences in fish. J Exp Biol 201:165-168

69. Whittington RJ, Reddacliff GL (1995) Influence of environmental temperature on experimental infection of redfin perch (Perca fluviatilis) and rainbow trout (Oncorhynchus mykiss) with epizootic haematopoietic necrosis virus-an Australian iridovirus. Aust Vet J 72:421-424
70. Ahne W, Ogawa M, Schlotfeldt HJ (1990) Fish viruses: transmission and pathogenicity of an icosahedral cytoplasmic deoxyribovirus isolated from sheatfish (Silurus glanis). Zentralbl Veterinarmed B 37(3):187-190

71. Brunner JL, Richards K, Collins JP (2005) Dose and host characteristics influence virulence of ranavirus infections. Oecologia 144:399-406

72. Ariel E, Bang Jensen B (2009) Challenge studies of European stock of redfin perch, Perca fluviatilis L. and rainbow trout, Oncorhyncus mykiss (Wallbaum) with epizootic haematopoietic necrosis virus (EHNV). J Fish Dis 32:1017-1025. doi:10.1111/ j.1365-2761.2009.01088.x

73. Bang Jensen B, Ohlemeyer S, Holopainen R, Schuetze H, Tapiovaara H, Bergmann SM and Ariel E. Susceptibility of European farmed freshwater fish to a panel of ranaviruses. (Accepted Journal of Fish Diseases) 